\title{
Dampak Keberadaan Minimarket terhadap Toko Kelontong di Pasar Klampis Kabupaten Bangkalan Madura
}

\author{
Zumrotul Muhzinat \\ Pascasarjana Ekonomi Islam Fakultas Ilmu Agama Islam/UII Yogyakarta, \\ Email: zumrotulmuhzinat83@gmail.com \\ Siti Achiria \\ Pascasarjana Ekonomi Islam Fakultas Ilmu Agama Islam/UII Yogyakarta, \\ Email: siti.achiria@uii.ac.id
}

\begin{abstract}
Abstrak:
This research was conducted to determine the impact of the presence of minimarkets on grocery stores in the Klampis Market, Bangkalan Madura. The emergence of modern markets such as Indomart and Alfamart can influence people's perceptions of decreasing turnover and the decreasing number of customers. This study uses a qualitative descriptive approach. The research location was conducted at several grocery stores around the Klampis market minimarket, Bangkalan Madura. The technique of determining informants in this study used purposive sampling. Data collection techniques in this study using Field Work Research.This study concluded that the existence of minimarkets caused the sellers of grocery stores to lose their customers and the income received also declined. However, this did not dampen the desire of grocery store traders to be able to compete with minimarkets, namely by providing basic necessities that were not available at the convenience store.

[Penelitian ini dilakukan untuk mengetahui dampak keberadaan minimarket terhadap toko kelontong di pasar Klampis Kabupaten Bangkalan Madura. Kemunculan pasar modern seperti Indomart dan Alfamart dapat berpengaruh terhadap persepsi masyarakat tentang menurunnya omset dan jumlah pelanggannya yang semakin berkurang. Penelitian ini menggunakan metode pendekatan deskriptif kualitatif. Lokasi penelitian di lakukan pada beberapa toko kelontong yang ada disekitar minimarket pasar Klampis Kabupaten Bangkalan Madura. Teknik penentuan informan dalam penelitian ini menggunakan purposive sampling. Teknik pengumpulan data dalam penelitian ini menggunakan Field Work Research. Penelitian ini menyimpulkan bahwa keberadaan minimarket menyebabkan para pedagang toko kelontong kehilangan konsumennya serta pendapatan yang diterima juga semakin menurun. Namun hal tersebut tak menyurutkan keinginan para pedagang toko kelontongan untuk dapat bersaing dengan minimarket yaitu dengan menyediakan barang-barang kebutuhan pokok yang tidak tersedia di minimarket.]
\end{abstract}

Kata Kunci: Pasar Modern; Pasar Tradisional; Strategi Pemasaran. 


\section{PENDAHULUAN}

Seiring berkembangnya zaman perusahaan ritel di Indonesia semakin banyak, mulai dari minimarket, supermarket dan hypermarket. Hal ini berdampak pada semakin banyaknya perusahaan ritel yang membuat masyarakat semakin dimanjakan oleh berbagai pusat perbelanjaan. Tumbuh pesatnya perusahaan ritel seperti minimarket di wilayah permukiman masyarakat mempunyai pengaruh positif dan negatif terhadap warung-warung kecil di sekitarnya. Kemunculan pasar modern seperti Indomart dan Alfamart juga berpengaruh terhadap persepsi masyarakat tentang menurunnya omset dan jumlah pelanggannya yang semakin berkurang.

Persaingan yang harus dihadapi pebisnis kecil yaitu semakin pesatnya pembangunan pasar modern yang banyak memberikan dampak terhadap keberadaan pasar tradisional yang sebagian besar memiliki usaha kecil perorangan. Di sisi lain, pasar modern dikelola secara professional dengan berbagai fasilitas yang lengkap, berbeda dengan pasar tradisional yang masih disibukkan dengan berbagai kendala seputar pengelolaan yang masih kurang efisien. Pasar modern dan pasar tradisional bersaing dalam pasar yang sama, yang disebut dengan pasar ritel. Perkembangan minimarket samakin pesat dan dikhawatirkan semakin lama semakin memberi dampak buruk bagi usaha kecil seperti usaha kelontong. ${ }^{1}$

Pasar di era modern ini tidak hanya berhubungan dengan jual beli barang dan proses tawar-menawar akan tetapi pasar juga mampu menyesuaikan gaya hidup masyarakat sehingga pasar dapat berkembangdan mampu menciptakan daya tarik tersendiri bagi masyarakat. Pengertian pasar secara fisik menurut Perpres RI No: 112 Tahun 2007 dalam jurnal penelitian yang dilakukan oleh Jamal, ${ }^{2}$ merupakan area tempat jual beli barang dengan jumlah penjual lebih dari satu dan biasa disebut sebagai pusat perbelanjaan, pasar tradisional maupun pasar modern.

Perkembangan pasar modern yang sangat pesat akan berdampak terhadap pasar tradisional. Hal ini dapat dilihat dari penerapan sistem pengelolaan yang profesional dalam pasar modern. Berbeda dengan pasar tradisional yang minim sarana prasarananya, sehingga muncul rasa ketidaknyamanan konsumen dalam berbelanja. Meskipun demikian pasar tradisional masih dapat bertahan dan bersaing di tengah pesatnya pertumbuhan pasar modern serta lebih mampu untuk mendukung kebutuhan konsumsi masyarakat. Proses pembelian juga menjadi pertimbangan bagi pelanggan. Di era yang modern seperti sekarang ini justru membuat konsumen lebih rasional dalam memilih tempat untuk berbelanja. Namun jika dilihat dari segi harga untuk pasar modern lebih tinggi jika dibandingkan dengan pasar tradisional. Meskipun demikian, konsumen tetap saja berbelanja di pasar modern dikarenakan harga yang ditawarkan sangat menarik dengan adanya penawaran diskon dan lain sebagainya. Menurut Sutikno, dalam jurnal penelitian yang dilakukan oleh Iffah, ${ }^{3}$ menyatakan bahwa preferensi konsumen terhadap pasar tradisional dan pasar modern dapat dilihat dari kelengkapan barang, kepastian harga, kualitas barang, kesopanan dan keramahan pedagang, kelengkapan fasilitas, kebersihan serta kenyamanan.

Eksistensi dari keberadaan pasar modern (minimarket) memiliki dampak yang cukup besar bagi para pedagang toko kelontong. Pasalnya kehadirannya telah membawa ancaman

\footnotetext{
1 Rina Walmiaty Mardi, "Dampak Munculnya Minimarket Waralaba Terhadap Usaha Kecil paa kemacetan Medan Tuntungan Sumatera Utara”, Proseding Seminar Nasional Balikpapan University Faculty of Economics Seminar national and Essay Competition, Vol. 1, No. 16, (Desember 2017).

${ }^{2}$ Abd. Jamal Annisa Hadif Nst, "Dampak Pasar Modern (Alfamart) Terhadap Usaha Pasar Tradisional Di Kabupaten Aceh Besar," Jurnal Ilmiah Mahasiswa (JIM), Vol. 3, No. 1, (2018).

${ }^{3}$ Melita Iffah, Fauzul Rizal Sutikno, and Nindya Sari, "Pengaruh Toko Modern Terhadap Toko Usaha Kecil Skala Lingkungan (Studi Kasus: Minimarket Kecamatan Blimbing, Kota Malang)," Jurnal Tata Kota dan Daerah, Vol. 3, No. 1, (2011).
} 
baru bagi para pedagang toko kelontong, bahkan akan ada yang harus menutup usahanya dikarenakan konsumennya berpindah. Hal ini menyebabkan para pedagang toko kelontong akan merasakan imbasnya secara langsung atas keberadaan pasar modern yakni minimarket. Salah satunya disebabkan oleh adanya penjualan produk yang sama di kedua tempat tersebut. Maka dari itu penulis menganggap penting melakukan penelitian dengan judul "Dampak Keberadaan Minimarket terhadap Toko Kelontong di Pasar Klampis Kabupaten Bangkalan Madura”.

\section{METODE PENELITIAN}

Penelitian ini menggunakan metode pendekatan deskriptif kualitatif. Menurut Moleong, penelitian deskriptif kualitatif merupakan data yang dikumpulkan dalam bentuk analisis bukan angka. Artinya data penyajian laporan dalam bentuk tulisan. ${ }^{4}$ Penelitian yang bersifat deskriptif bertujuan untuk menggambarkan secara tepat sifat-sifat individu dan keadaan sosial yang timbul dalam masyarakat untuk dijadikan objek penelitian. Metode deskriptif adalah suatu metode dalam meneliti status sekelompok manusia atau objek, suatu set kondisi, ataupun sistem pemikiran dan peristiwa yang sedang terjadi sekarang. ${ }^{5}$ Penelitian ini dilakukan pada beberapa toko kelontong yang ada disekitar lokasi minimarket pasar Klampis Kabupaten Bangkalan Madura, karena melihat peran pasar tradisional yang mulai terbengkalai akibat keberadaan beberapa minimarket yang ada disekitarnya.

Teknik penentuan informan dalam penelitian ini menggunakan purposive sampling. Teknik purposive sampling yaitu teknik penentuan informan berdasarkan kriteria dan pertimbangan tertentu. Informan yang digunakan dalam penelitian ini merupakan pemilik atau karyawan yang bekerja secara langsung di toko kelontong yang ada disekitar lokasi minimarket serta konsumen yang sering atau baru berbelanja di minimarket sebagai informan pendukung. ${ }^{6}$ Teknik pengumpulan data dalam penelitian ini menggunakan Field Work Research yaitu penelitian yang akan dilakukan secara langsung dilapangan menggunakan teknik wawancara, observasi, kepustakaan dan dokumentasi untuk melengkapi keterangan yang berkaitan dengan penelitian. ${ }^{7}$ Sumber data yang digunakan dalam penelitian ini yaitu sumber data primer yang diperoleh dari hasil obeservasi, wawancara dan dokumentasi.

\section{HASIL DAN PEMBAHASAN}

\section{Dampak Keberadaan Minimarket terhadap Toko Kelontong di Pasar Klampis Kabupaten Bangkalan Madura}

Pada dasarnya pasar modern (minimarket) dan pasar tradisional (toko kelontong) memiliki segmentasi pasar yang berbeda. Pasalnya di pasar tradisional masih terjadi proses tawar menawar harga yang dapat memungkinkan terjadinya kedekatan personal dan emosional antara penjual dan pembeli yang tidak ada di pasar modern. Namun keunggulan pasar modern memiliki kemampuan kerjasama yang cukup baik dengan beberapa para pemasok, sehingga menyebabkan terjadinya efisiensi melalui skala ekonomi yang cukup besar dan beberapa strategi yang tidak ditemukan di pasar tradisional, seperti strategi non

\footnotetext{
4Mahmudah Masyhuri and Supri Wahyudi Utomo, "Analisis Dampak Keberadaan Pasar Modern Terhadap Pasar Tradisional Sleko Di Kota Madiun," Assets: Jurnal Akuntansi dan Pendidikan, Vol. 6, No. 1, (2017).

${ }^{5}$ Aldinur Armi, dkk, "Dampak Sosial Ekonomi Kebijakan Relokasi Pasar (Studi Kasus Relokasi Dinoyo Malang)", Jurnal Administrasi Publik (JAP), Vol. 4, No. 10.

${ }^{6}$ Aan Prabowo and Heriyanto, "Analisis Pemanfaatan Buku Elektronik (E-Book) Berbasis Web Oleh Pemustaka Di Perpustakaan Sma Negeri 1 Semarang," Jurnal Ilmu Perpustakaan, Vol. 2, No. 2, (2013).

${ }^{7}$ Ayu Ulfiani Hidayah, "Analisis Pelaksanaan Relokasi Pedagang Kaki Lima Di Pasar Simpang Padang Duri Kecamatan Mandau Kabupaten Bengkalis," Jom Fisip, Vol. 4, No. 1, (Februari 2017).
} 
harga, yakni jam buka lebih lama ataupun adanya tempat parkir gratis. Hal ini menjadi salah satu penyebab berkembangnya pasar tradisional menjadi lambat dikarenakan minimnya daya dukung karakteristik pedagang tradisional seperti strategi perencanaan yang kurang baik, tidak adanya economies of scale, dan ketidakmampuan dalam menyesuaikan kebutuhan yang diinginkan konsumen. ${ }^{8}$

Menurut Moersid, bahwa pasar modern menggunakan prinsip swalayan, yakni mengambil barang sendiri. Pasar modern juga disebut dengan pasar yang telah tersusun dan sudah diatur. Pasalnya harga barang yang ditawarkan oleh pasar modern sudah tidak bisa ditawar lagi. Pasar modern pun telah menjadi sarana brand internasional untuk memperluas produknya sampai ke target pasar. ${ }^{9}$ Pengertian pasar modern menurut Hutabarat, yaitu suatu pasar dimana penjual dan pembeli tidak melakukan transaksi secara langsung. Pembeli hanya melihat harga pada satuan kemasan produk dan dilayani secara mandiri oleh pramuniaganya. ${ }^{10}$ Dari pengertian tersebut dapat disimpulkan bahwa pasar modern adalah pasar yang terstruktur dan sudah diatur dimana penjual dan pembelinya tidak melakukan transaksi secara langsung melainkan dilayani secara mandiri oleh pramuniaga serta tidak adanya tawar menawar atas barang yang diperjual belikan.

Pasar modern dan pasar tradisional dapat bersaing di satu tempat yang sama karena pada dasarnya hampir semua barang yang dijual di pasar tradisional juga dapat ditemukan di pasar modern (minimarket), seperti Indomaret dan Alfamart. Fenomena semacam ini akan berpengaruh terhadap keduanya. Pasalnya jarak antara minimarket dan toko kelontong yang sangat berdekatan memicu terjadinya persaingan mulai dari pendapatan hingga jumlah konsumen yang ingin berbelanja. Hal ini akan membentuk suatu segmentasi persaingan antara minimarket dan toko kelontong. Seperti yang diungkapkan oleh Ibu Satun pemilik toko kelontong menyatakan bahwa:"jika lokasi dan keberadaan minimarket berdekatan maka kemungkinan besar konsumen akan lebih memilih untuk berbelanja di minimarket. Namun ada beberapa konsumen yang lebih memilih berbelanja disini lantaran harga bahan pokok yang ditawarkan jauh lebih ekonomis dibanding harga bahan pokok di minimarket". (hasil wawancara, 25 Juni 2019).

Banyaknya minimarket yang tumbuh di masyarakat memiliki keuntungan dan kerugian. Keuntungan yang didapat yaitu terpenuhinya kebutuhan konsumen serta dapat mengurangi tingkat pengangguran yang ada dengan membuka lowongan pekerjaan bagi masyarakat sekitarnya. Sedangkan kerugian yang didapat yaitu penurunan jumlah konsumen dalam memilih tempat untuk berbelanja, meskipun demikian ada sebagian masyarakat yang lebih memilih berbelanja di toko kelontong dibanding berbelanja di minimarket. Penjelasan tersebut didukung penelitian yang dilakukan oleh Lestari,11 bahwa permasalahan yang terjadi pada pasar tradisional tidak sepenuhnya disebabkan oleh keberadaan pasar modern yang semakin berkembang pesat. Permasalahan ini muncul disebabkan oleh faktor internal yang sering dihadapi oleh penjual toko kelontong seperti retribusi dan kesadaran pedagang dalam membayar retribusi pasar.

Keberadaan pasar tradisional saat ini semakin terdesak dengan keberadaan pasar modern yang semakin berkembang dan memberikan kenyamanan serta pelayanan yang lebih

\footnotetext{
8 Andi Ainda Lestari, "Dampak Keberadaan Pasar Modern Terhadap Eksistensi Pasar Tradisional Di Kota Samarinda”, e-Journal Administrasi Bisnis, Vol. 4, No. 2, (2018).

${ }^{9}$ T. Zaulham Kasman Rasyidin, "Dampak Kemunculan Pasar Modern Terhadap Pedagang Pasar Tradisional Di Kota Banda Aceh," Jurnal Ilmiah Mahasiswa (JIM), Vol. 2, No. 1, (2017).

${ }^{10}$ Abd. Jamal Annisa Hadif Nst, "Dampak Pasar Modern (Alfamart) Terhadap Usaha Pasar Tradisional Di Kabupaten Aceh Besar," Jurnal Ilmiah Mahasiswa (JIM), Vol. 3, No. 1, (2018).

11 Andi Adinda LestariAnd, "Dampak Keberadaan Pasar Modern Terhadap Eksistensi Pasar Tradisional Di Kota Samarinda," eJournal Administrasi Bisnis, Vol. 6, No. 2, (2018).
} 
baik dibandingkan dengan pelayanan di pasar tradisional. Pasalnya semakin banyaknya pasar modern akan membuat pasar tradisional semakin terabaikan. Ditambah lagi persepsi masyarakat yang mengatakan bahwa barang yang ditawarkan di pasar tradisional tidak berkualitas dengan pelayanan yang tidak memuaskan. ${ }^{12}$ Berdasarkan data Nielsen pada tahun 2010 menjelaskan bahwa pertumbuhan alfamart mencapai 4.000 gerai dan pertumbuhan indomart mencapai 4.110 gerai. Perkembangan pasar modern ini menunjukkan terjadinya persaingan antara pasar modern dan pasar tradisional baik dari segi harga, kualitas barang, sarana prasarana, maupun pelayanannya. ${ }^{13}$

Keadaan ini juga akan berdampak pada pendapatan toko kelontong yang semakin menurun. Penurunan ini mengakibatkan kelesuan bagi para pedagangnya, sehingga toko tidak menarik lagi untuk dikelola. Dikarenakan pedagang tidak mamapu lagi menambah jumlah produk yang ada ditokonya dan tidak mampu mengembangkan tokonya dengan baik akibat dari modal yang menurun. Kebanyak dari pedagang toko kelontongan adalah pedagang yang memiliki inisiatif sendiri untuk memulai bisnisnya sehingga bisa dibilang manajemennya kurang baik seperti masalah bauran pemasaran baik produk, harga, distribusi maupun promosi. ${ }^{14}$ Maka dapat disimpulkan bahwa dampak adanya pasar modern terhadap pasar tradisional yaitu adanya persepsi masyarakat tentang kenyamanan menggunakan produk dan pelayanan di pasar modern dibandingkan produk dan pelayanan di pasar tradisional. Sehingga pasar tradisional kurang diperhatikan dan bahkan terabaikan oleh sebagian konsumennya.

\section{Pendapat Konsumen tentang Dampak Keberadaan Minimarket terhadap Toko Kelontong di Pasar Klampis Kabupaten Bangkalan Madura}

Meningkatnya pertumbuhan minimarket berdampak terhadap penurunan daya saing pasar tradisional (toko kelontong). Meskipun keputusan pembelian merupakan kehendak konsumen masing-masing untuk memenuhi tingkat kebutuhannya, namun salah satu hal yang tidak dapat dipungkiri adalah berkembangnya gaya hidup modern masyarakat di sekitar pasar Klampis, mulai menyukai hal-hal yang lebih mudah dan praktis membuat masyarakat yang ada di sekitar pasar Klampis ini tertarik untuk berbelanja di minimarket. Beberapa masyarakatpun mengakui bahwa berbelanja di minimarket lebih menyenangkan dibandingkan berbelanja di pasar tradisional dengan alasan di minimarket mereka mampu berbelanja tanpa harus antri dan lebih fleksibel dalam memilih barang-barang sesuai kebutuhannya.

Faktor-faktor yang dapat mempengaruhi minat pembeli berhubungan dengan perasaan dan emosi, apabila seseorang merasa senang dan puas dalam membeli barang maka hal itu akan memperkuat minat pembeli, ketidakpuasannya biasanya menghilangkan minat. Strategi pemasaran yang dilakukan oleh pedagang tradisional (toko kelontong) yaitu dengan cara adanya bauran pemasaran. Dari bauran pemasaran tersebut lebih ditekankan kepada penekanan harga yang lebih murah, kelengkapan dan keberagaman produk barang dagangan

\footnotetext{
12Dampak Relokasi, Pasar Wedi, and Ardhi Yunandar, "The Impact of the Relocation of Wedi Market Against the Socio- Economic Conditions of the Traders in the Wedi Market" (n.d.).

${ }^{13}$ Nirmala Mustika Dewi, "Resistensi Pedagang Terhadap Implementasi Kebijakan Relokasi Pasar Waru Sidoarjo," Jurnal Politik Muda, Vol. 4, No. 1, (2015).

14 N.K Seminari, dkk, "Meningkatkan Manajemen Toko Kelontong Dalam Menghadapi Ritel Modern Di Desa Mengwi Kabupaten Bandung”, Buletin Udayana Mengabdi, Vol. 16, No. 3, (September 2017).
} 
yang dijual serta beragam. Dengan demikian, barang dagangan yang ditawarkan akan diminati dan jumlah penjualan semakin meningkat dalam menghadapi persaingan. ${ }^{15}$

Pasar tradisional identik dengan konsisi yang kumuh dan jorok. Terlebih bahwa pelayanan di pasar tradisional sering terjadi manipulasi terhadap kualitas dan kuantitas barang yang ditawarkan sehingga mengurangi tingkat kepercayaan dan ketertarikan konsumen untuk berbelanja dipasar tradisional. Pengertian pasar tradisional adalah suatu tempat dimana penjual dan pembeli melakukan transaksi secara langsung dan mengadakan proses tawar menawar terhadap barang kebutuhan pokok yang diperjualbelikan. ${ }^{16}$ Pendapat yang sama juga disampaikan oleh Rahayu dan Bahari, bahwa pasar tradisional adalah pasar yang dikelola dengan sistem yang tradisional dan lebih simpel dibanding pasar modern. ${ }^{17}$

Kehadiran pasar modern di pasar Klampis memberikan pengaruh terhadap nilai sosial masyarakatnya. Meskipun ada sebagian konsumen yang tetap berbelanja di toko kelontong, tetapi ada juga konsumen yang beralih ke minimarket karena barang yang tersedia di minimarket lebih berkualitas dibandingkan barang yang tersedia di toko kelontong. Seperti yang diungkapkan oleh Lely salah satu konsumen minimarket:

"masyarakat yang lebih memilih berbelanja di minimarket dikarenakan produk yang ditawarkan di minimarket lebih berkualitas dari pada produk yang ditawarkan oleh toko kelontong, tingkat pelayanan selama 24jam yang baik dan canggih, kebersihan tempat dan sebagainya sehingga dapat meningkatkan daya tarik konsumen untuk berbelanja di minimarket. Berbelanja di minimarket juga dapat difaktori oleh gaya hidup yang elit dan modern mengikuti perkembangan zaman, tersedia bank mini juga untuk memudahkan para konsumen untuk melakukan penarikan tunai, melayani pembokingan tiket, pulsa elektronik serta tersedianya lahan parkir untuk para konsumen"18.

Hasil wawancara dari informan dapat disimpulkan bahwa konsumen lebih memilih berbelanja di minimarket disebabkan oleh beberapa faktor seperti gaya hidup, tingkat kenyaman dan tingkat kebersihan yang ada di minimarket. Namun hal tersebut akan memiliki dampak yang negatif terhadap pedagang toko kelontong karena jumlah pelanggan berkurang akan mempengaruhi tingkat keuntungan para pedagang. Walaupun produk yang ditawarkan di minimarket dan toko kelontong hampir sama namun variasi dan tata letak produk di minimarket lebih rapih sehingga membuat konsumen mudah dalam memilih produk yang akan dibelinya dan sesuai dengan kebutuhannya.

Hal ini didukung oleh penelitian yang dilakukan oleh Kasman,19 bahwa munculnya pasar modern lebih diminati oleh para konsumen karena sistem pemasaran seperti harga, barang, tempat dan promosi memberikan pengaruh yang lebih unggul dibandingkan dengan pasar tradisional (toko kelontong). Menurut Kotler dan Killer, bahwa pemasaran sendiri merupakan suatu proses kegiatan menawarkan dan menyediakan barang untuk memenuhi kebutuhan individu maupun kelompok dan secara bebas menukarkan produk yang bernilai dengan pihak lain. Pendapat yang sama juga disampaikan oleh Kismono, bahwa pemasaran adalah suatu aktivitas yang dilakukan untuk merancang berbagai kebutuhan konsumen

\footnotetext{
15 Indria Yuli Susanti, “Analisis Pengaruh Strategi Pemasaran Toko Kelontong Dalam Memengaruhi Minat Beli Konsumen Menghadapi Persaingan Toko Modern (Studi Kasus Toko Kelotong Di Kecamatan Sumbersari Kabupaten Jember", Jurnal Ekonomika, Vol.9, No. 2, (Desember 2016).

${ }^{16}$ Nel Ariyanti, "Analisis Perbedaan Pasar Modern Dan Pasar Tradisional Ditinjau Dari Strategi Tata Letak (Lay Out) Dan Kualitas Pelayanan Untuk Meningkatkan Posisi Tawar Pasar Tradisional," Jurnal Manajemen \& Bisnis, Vol. 13, No. 1, (2013).

${ }^{17}$ Mahmudah Masyhuri and Supri Wahyudi Utomo, "Analisis Dampak Keberadaan Pasar Modern Terhadap Pasar Tradisional Sleko Di Kota Madiun," Assets: Jurnal Akuntansi dan Pendidikan, Vol. 6, No. 1, (2017). 18 Wawancara 28 Juni 2019

${ }^{19} \mathrm{~T}$. Zaulham Kasman Rasyidin, "Dampak Kemunculan Pasar Modern Terhadap Pedagang Pasar Tradisional Di Kota Banda Aceh," Jurnal Ilmiah Mahasiswa (JIM), Vol. 2, No. 1, (2017).
} 
melalui proses distribusi, promosi dan penetapan harga terhadap beberapa produk yang ditawarkan. ${ }^{20}$ Maka dapat disimpulkan bahwa pemasaran adalah proses yang dilakukan produsen dalam memasarkan dan menawarkan produknya melalui proses pendistribusian, promosi maupun penetapan harga guna memenuhi kebutuhan dan keinginan individu maupun kelompok.

\section{Strategi Toko Kelontong dalam Menghadapi Tantangan Dampak Keberadaan Minimarket terhadap Toko Kelontong di Pasar Klampis Kabupaten Bangkalan Madura}

Dampak yang terjadi akibat berkembangnya minimarket, membuat para pedagang toko kelontong harus melakukan strategi agar dapat bersaing, baik dari segi produk yang tawarkan, pelayanan maupun pemasarannya. Hal ini sesuai dengan yang diungkapkan oleh Ibu Hikmah pemilik toko kelontong:

"strategi yang saya lakukan untuk dapat bersaing seiring dengan berkembangnya minimarket, saya menyediakan bahan-bahan kebutuhan pokok yang tidak dijual ataupun yang tidak terdapat di minimarket salah satunya saya menjual bensin eceran, minyak gorng eceran, beras eceran, rempah-rempah, isi ulang tabung gas dan sebagainyakarena menurut saya tidak semua konsumen membeli kebutuhannya dalam jumlah yang banyak, pastinya mereka akan membeli sesuai kadar kebutuhannya saja. Makanya saya menjual beberapa kebutuhan yang bisa diecer. Saya lakukan itu juga untuk menambah tingkat pendapatan. sayapun menjual barang dagang saya dengan harga yang lebih murah dibandingkan harga yang ditawarkan di minimarket. Jika pedagang toko kelontong seperti saya tidak melakukan hal tersebut bisa jadi usaha saya akan gulung tikar lantaran para konsumen saya beralih ke minimarket." 21

Beberapa pemilik toko kelontong melakukan hal yang sama, tetapi ada beberapa pemilik toko kelontong yang tidak respon sama sekali terhadap adanya minimarket di dekat tokonya.

Adanya berbagai penelitian dan kajian yang dilakukan oleh beberapa para ahli mengenai persaingan pasar tradisional dan pasar modern telah menghasilkan banyak masukan yang berguna bagi pasar tradisional sebagai pihak yang berada di posisi lemah dalam persaingannya dengan pasar modern. Dalam penelitiannya, Syatibi memberikan solusi kepada para pedagang tradisional dalam menghadapi tekanan maupun tantangan bersaing dengan pasar modern. Pasar tradisional dapat melakukan strategi bersaing melalui penerapan strategi pengembangan saling menguntungkan. Pertama, adanya kolaborasi dalam akses pasar serta kolaborasi pemasok dalam mensupplay produk-produk yang bermutu. Kedua, meningkatkan pelayanan. Ketiga, mempermudah akses pemberian bantuan pinjaman modal bagi para pedagang tradisional agar dapat melakukan perluasan bisnia. Keempat, pemerintah sebaiknya lebih memperhatikan pasar tradisional serta perihal perizinan masuknya pasar modern seperti minimarket dan sebagainya. ${ }^{22}$

Adapun langkah yang harus dilakukan oleh penjual toko kelontong untuk dapat bersaing dengan pasar modern (minimarket) yaitu membuat suatu perubahan dalam strategi pemasarannya, yakni dengan cara meningkatkan penjualannya agar mampu bersaing serta prospek kerjanyapun dapat terjaga. Beberapa strategi yang dapat dilakukan oleh para penjual toko kelontong. Pertama, penyediaan barang dagang seharusnya disesuaikan dengan kebutuhan konsumen, hal ini dapat dilakukan melalui survei terhadap barang aau produk

\footnotetext{
${ }^{20}$ Andi Adinda Lestari, "Dampak Keberadaan Pasar Modern Terhadap Eksistensi Pasar Tradisional Di Kota Samarinda," e Journal Administrasi Bisnis, Vol. 6, No. 2, (2018).

21 Wawancara 1 Juli 2019

22 Tri Joko Utomo, "Persaingan Bisnis Ritel: Tradisional Vs Modern”, Fokus Ekonomi, Vol. 6, No. 1, (Juni 2011).
} 
yang diminati konsumen. Kedua, penataan barang harus rapi dan sepadat mungkin agar terlihat oleh pembeli dan mendorong pembeli untuk melakukan konsumsi. Ketiga, penetapan harga hendaknya disesuaikan dengan kondisi masyarakat yang ada disekitarnya. Hal ini bisa disesuaikan dengan merk produk yang sedang dijualnya. Keempat, memberi pilihan harga. Yakni menyediakan produk yang sama dengan merk dan harga yang bervariasi, sehingga pembeli dapat lebih mudah menentukan pilihannya. Kelima, memasang harga di depan toko. Hal ini merupakan salah satu bentuk promosi yang dapat dilakukan oleh para pedagang toko kelontong. Keenam, menyediakan ruang yang nyaman dan memiliki ruang gerak yang cukup dengan menata barang seefisien mungkin dan tanggap terhadap pembeli agar tidak sampai antri.23

Toko kelontong yang sebagian besar dimiliki oleh masyarakat individu haruslah mengutamakan loyalitas konsumennya. Hal ini dipandang perlu dilakukan karena dapat bertujuan untuk meningkatkan pendapatan toko. Beberapa hal yang perlu dilakukan untuk meningkatkan loyalitas konsumen diantaranya yaitu melihat customer sastisfaction atau pelayanan prima dari toko tersebut karena untuk dapat mendongkrak penjualan produk bukanlah suatu hal yang mudah dilakukan. Adapun cara untuk meningkatkan penjualan produk toko kelontong yang dapa dilakuakan. Pertama, barang yang dijual di toko kelontong harus variatif meskipun tidak perlu selengkap minimarket modern, dalam artian utamakan barang-barang yang banyak dibutuhkan dasar atau oleh pembeli. Kedua, lakukan pembukan secara administrative dan sederhana dengan mencatat segala biaya pembelian. Ketiga, mengutamakan kualitas produk yang sudah menjadi syarat utama bagi pelaku bisnis untuk meningkatkan penjualan produk. ${ }^{24}$

\section{PENUTUP}

Hasil penelitian ini menyimpulkan bahwa dampak keberadaan minimarket terhadap toko kelontong di pasar Klampis Kabupaten Bangkalan Madura menyebabkan para pedagang toko kelontong kehilangan konsumennya dan pendapatan yang diterima juga semakin menurun. Namun demikian, hal tersebut tidak menyurutkan keinginan para pedagang toko kelontongan untuk tetap mampu bersaing dengan minimarket. Strategi yang digunakan dengan menyediakan barang-barang kebutuhan pokok yang tidak tersedia di minimarket, salah satu contohnya, mereka menjual bensin eceran sebagai sumber penghasilan. Toko kelontong yang sebagian besar dimiliki oleh masyarakat individu haruslah mengutamakan loyalitas konsumennya. Hal ini perlu dilakukan karena dapat meningkatkan pendapatannya. Langkah yang harus dilakukan oleh penjual toko kelontong untuk dapat bersaing dengan pasar modern (minimarket) yaitu membuat suatu perubahan dalam strategi pemasarannya, yakni dengan cara meningkatkan penjualannya dan prospek kerjanya agar mampu bersaing.

Penulis menyarankan kepada pemerintah untuk dapat meminimalisir pembangungan minimarket yang berdampak pada penurunan tingkat pendapatan para pedagang toko kelontong dan warung-warung kecil di sekitarnya. Penelitian ini juga menyarankan kepada pedagang toko kelontong untuk memberikan pelayanan yang lebih baik kepada konsumen, menjaga kebersihan tokonya dan menyediakan berbagai macam varian produk yang dibutuhkan oleh sebagian konsumen pada umumnya.

\footnotetext{
23 Rusno, “Dampak Pesatnya Minimmarket Waralaba terhadap Usaha Kecil (Jenis Ritel)”, Jurnal Ekonomi Modernisasi, Vol. 4, No. 3 (Oktober 2008).

${ }^{24}$ Heny Yuningrum, "Usaha Untuk Meningkatkan Loyalitas Toko Kelontong Dalam Menghadapi Usaha Ritel Yang Menjamur Dimasyarakat”, Economica, Vol. 7, No. 2, (Oktober 2016).
} 


\section{DAFTAR PUSTAKA}

Annisa Hadif Nst, Abd. Jamal. "Dampak Pasar Modern (Alfamart) Terhadap Usaha Pasar Tradisional Di Kabupaten Aceh Besar." Jurnal Ilmiah Mahasiswa (JIM) 3, no. 1 (2018): 59-67.

Ariyanti, Nel. "Analisis Perbedaan Pasar Modern Dan Pasar Tradisional Ditinjau Dari Strategi Tata Letak (Lay Out) Dan Kualitas Pelayanan Untuk Meningkatkan Posisi Tawar Pasar Tradisional." Jurnal Manajemen \& Bisnis 13, no. 1 (2013): 18-29.

Dewi, Nirmala Mustika. "Resistensi Pedagang Terhadap Implementasi Kebijakan Relokasi Pasar Waru Sidoarjo." Jurnal Politik Muda 4, no. 1 (2015): 126-136.

Hidayah, Ayu Ulfiani. "Analisis Pelaksanaan Relokasi Pedagang Kaki Lima Di Pasar Simpang Padang Duri Kecamatan Mandau Kabupaten Bengkalis." Jom Fisip 4, no. 1 Februari (2017): 1-10.

Iffah, Melita, Fauzul Rizal Sutikno, and Nindya Sari. "Pengaruh Toko Modern Terhadap Toko Usaha Kecil Skala Lingkungan (Studi Kasus : Minimarket Kecamatan Blimbing, Kota Malang)." Jurnal Tata Kota dan Daerah 3, no. 1 (2011): 55-64.

Kasman Rasyidin, T. Zaulham. "Dampak Kemunculan Pasar Modern Terhadap Pedagang Pasar Tradisional Di Kota Banda Aceh." Jurnal Ilmiah Mahasiswa (JIM) 2, no. 1 (2017): 125-133.

Lestari, Andi Adinda. "Dampak Keberadaan Pasar Modern Terhadap Eksistensi Pasar Tradisional Di Kota Samarinda." eJournal Administrasi Bisnis 6, no. 2 (2018): 700-712.

Masyhuri, Mahmudah, and Supri Wahyudi Utomo. "Analisis Dampak Keberadaan Pasar Modern Terhadap Pasar Tradisional Sleko Di Kota Madiun.” Assets: Jurnal Akuntansi dan Pendidikan 6, no. 1 (2017): 59-72.

Prabowo, Aan, and Heriyanto. "Analisis Pemanfaatan Buku Elektronik (E-Book) Berbasis Web Oleh Pemustaka Di Perpustakaan Sma Negeri 1 Semarang." Jurnal Ilmu Perpustakaan 2, no. 2 (2013): 1-9. http://ejournal-s1.undip.ac.id/index.php/jip.

Relokasi, Dampak, Pasar Wedi, and Ardhi Yunandar. "The Impact of the Relocation of Wedi Market Against the Socio- Economic Conditions of the Traders in the Wedi Market" (n.d.).

Rusno, "Dampak Pesatnya Minimarket Waralaba terhadap Usaha Kecil (Jenis Ritel)", Jurnal Ekonomi Modernisasi, Vol. 4, No. 3 (Oktober 2008).

N.K Seminari, dkk, "Meningkatkan Manajemen Toko Kelontong Dalam Menghadapi Ritel Modern Di Desa Mengwi Kabupaten Bandung", Buletin Udayana Mengabdi, Vol. 16, No. 3, (September 2017).

Rina Walmiaty Mardi, "Dampak Munculnya Minimarket Waralaba Terhadap Usaha Kecil paa kemacetan Medan Tuntungan Sumatera Utara", Proseding Seminar Nasional Balikpapan University Faculty of Economics Seminar national and Essay Competition, Vol. 1, No. 16, (Desember 2017).

Indria Yuli Susanti, "Analisis Pengaruh Strategi Pemasaran Toko Kelontong Dalam Memengaruhi Minat Beli Konsumen Menghadapi Persaingan Toko Modern (Studi Kasus Toko Kelotong Di Kecamatan Sumbersari Kabupaten Jember", Jurnal Ekonomika, Vol.9, No. 2, (Desember 2016).

Tri Joko Utomo, "Persaingan Bisnis Ritel: Tradisional Vs Modern", Fokus Ekonomi, Vol. 6, No. 1, (Juni 2011).

Aldinur Armi, dkk, "Dampak Sosial Ekonomi Kebijakan Relokasi Pasar (Studi Kasus Relokasi Dinoyo Malang)”, Jurnal Administrasi Publik (JAP), Vol. 4, No. 10. 